\title{
Testing of thermal fatigue resistance of tools and rolls for hot working
}

\section{Testiranje orodij in valjev za delo v vročem na odpornost proti temperaturnemu utrujanju}

\author{
Milan Terčelj ${ }^{1},{ }^{*}$, Matevž Fazarinc', Goran Kugler ${ }^{1}$ \\ 'University of Ljubljana, Faculty for Natural Sciences and Engineering, Department for Materials and Metallurgy, \\ Aškerčeva 12, 1000 Ljubljana, Slovenia \\ *milan.tercelj@ntf.uni-lj.si
}

\begin{abstract}
:
In the present contribution two tests for thermal fatigue testing, which have been developed in our group, are presented. First test has provided internal cooling system of sample, while second has external cooling. For both tests heating and cooling of samples are computer guided that enables very reliable results of testing. The first test is more appropriate for testing the base material, i.e. roll cast irons, roll steels, tool steels. The second test is more appropriate for experiments that are aimed for selection of appropriate tool surface treatment, i.e. laser cladding, nitriding, coating, etc., and to compare and to achieve improved resistance against thermal fatigue of produced surface layers.
\end{abstract}

Key words: thermal fatigue, test rigs, tool steel, roll cast iron, laser cladding

\section{Povzetek:}

$\mathrm{V}$ prispevku sta predstavljena dva razvita testa namenjena za študij odpornosti na temperaturno utrujanje. Pri prvem testu je hlajenje testiranega vzorca izvedeno na notranji strani, pri drugem testu pa je hlajenje vzorca izvedeno na zunanji strani. Oba testa imata računalniško vodeno tako ogrevanje kot tudi ohlajanje vzorca, kar omogoča pridobivanje zanesljivih podatkov o obstojnosti na temperaturno utrujanje. Prvi test je bolj primeren za testiranje odpornosti na utrujanje osnovnih materialov kot so, npr. valji iz litega železa in jekla ter orodna jekla za delo v vročem. Drugi test je bolj primeren za testiranje odpornosti na temperaturno utrujanje površinsko obdelanih orodij za delo v vročem kot, npr. lasersko navarjanje, nitridiranje, oplaščenje, itd. Ker je omogočeno istočasno testiranje več površinskih plasti na vzorcu, lahko različno pripravljene površinske plasti med sabo neposredno primerjamo na njihovo odpornost na temperaturno utrujanje.

Ključne besede: termično utrujanje, testne naprave, orodno jeklo, lito železo za valje, lasersko navarjanje 


\section{Introduction}

Thermal fatigue resistance is very important characteristics of base tool steels (e.g. roll cast irons, roll steels, tool steels). It is also important for evaluation of their relation with various surface treatments procedures (e.g. nitriding, duplex treatment, etc) and processing. Reliable testing is important for revealing the optimal process parameters of tool steel production or parameters of surface layer preparation for their individual application. The laboratory test rig (equipment) for their evaluation must be capable of carrying out such tests at various temperatures and must have the capability to generate various temperature (stress) fields at the selected testing temperature. Usage of those conditions is necessary in order to better evaluate the usage of materials or treated surface layer for a specific application. The tests that can be found in the literature cannot fulfil the above-mentioned tasks satisfactorily $[1,2]$. Poor knowledge of the temperature field within the specimen, and consequently also poor knowledge of the stress/strain field, results in an inaccurate estimation of the influence of parameters that are responsible for the nucleation and growth of cracks. In the past years an increased demand for improvement of experimental data for better numerical modelling of crack growth can be found in the literature. Quenching in water is a very popular method to measure thermal fatigue resistance, but it has some weaknesses due to the unknown heat transfer coefficient as a consequence of the vaporisation of water in the vicinity of the tested specimen surface [1-4]. Some authors designed special nozzles in order to minimize the effect of water vaporisation [5]. Marsh et al. [6], Amiabe et al. [4] and Hadder et al. [7] applied the so-called SPLASH test that also utilises water quenching of samples to generate temperature fields. Pellizzari et al. [8] used fatigue test with water cooling whereas effect of vaporisation of water was considerably decreased. Although they made great progress in modelling of crack growth on the basis of the experimental data, further experimental improvements in this area of research are desired.

Therefore, the goal of this paper is to present two new test rigs for better evaluation of ther- mal fatigue resistance of tool materials and their prepared surface. These test rigs enable generation of high and repeated thermal stress with well-defined thermal boundary conditions. Results of tests of different laser cladded material will be presented for better comparative evaluation of thermal fatigue resistance of tested materials.

\section{Description of developed tests and materials}

Two types of test rigs were used for thermal fatigue testing. The first test rig with corresponding shape of specimen is schematically presented in Figure 1a-b while the second test rig with corresponding circles or octagonal cross-section of the specimen and thermocouple welded on internal side of specimen is presented on Figure 1c-e, respectively. As shows Figure 1d the testing part (working length) of the octagonal shaped specimen (i.e. its cross-section is octagonal), was placed in a cooling chamber whereas water inlet and its outlet is presented.

\section{Test rig 1, materials and test conditions}

From the Figures $1 \mathrm{a}-\mathrm{b}$ is visible, that at first test rig cooling is performed on internal side wherein thermocouple is welded on outside of specimen. This test is more appropriate for thermal fatigue testing of the tool material with its chemical composition aimed for specific application as well as for study of influence of process parameters of steel (cast iron) production on thermal fatigue resistance. The hollow specimen is on both sides tightly clamped between two cooper anvils which are placed in working cells of Gleeble 1500D thermo-mechanical simulator. On middle of working length $(12 \mathrm{~mm})$ of test samples thermocouple wires of type $\mathrm{K}$ are welded while water and air inlet as well as their outlet from samples is enabled by tubes that are fixed on its lateral sides. Heating of specimen and its cooling by water and air flow through hollow specimen is computer guided which provides constant testing conditions, i.e. achieving of constant heating to test temperature as well as specimen internal cooling, are assured. Regarding to programmed heating, specimens were heated to selected tempera- 

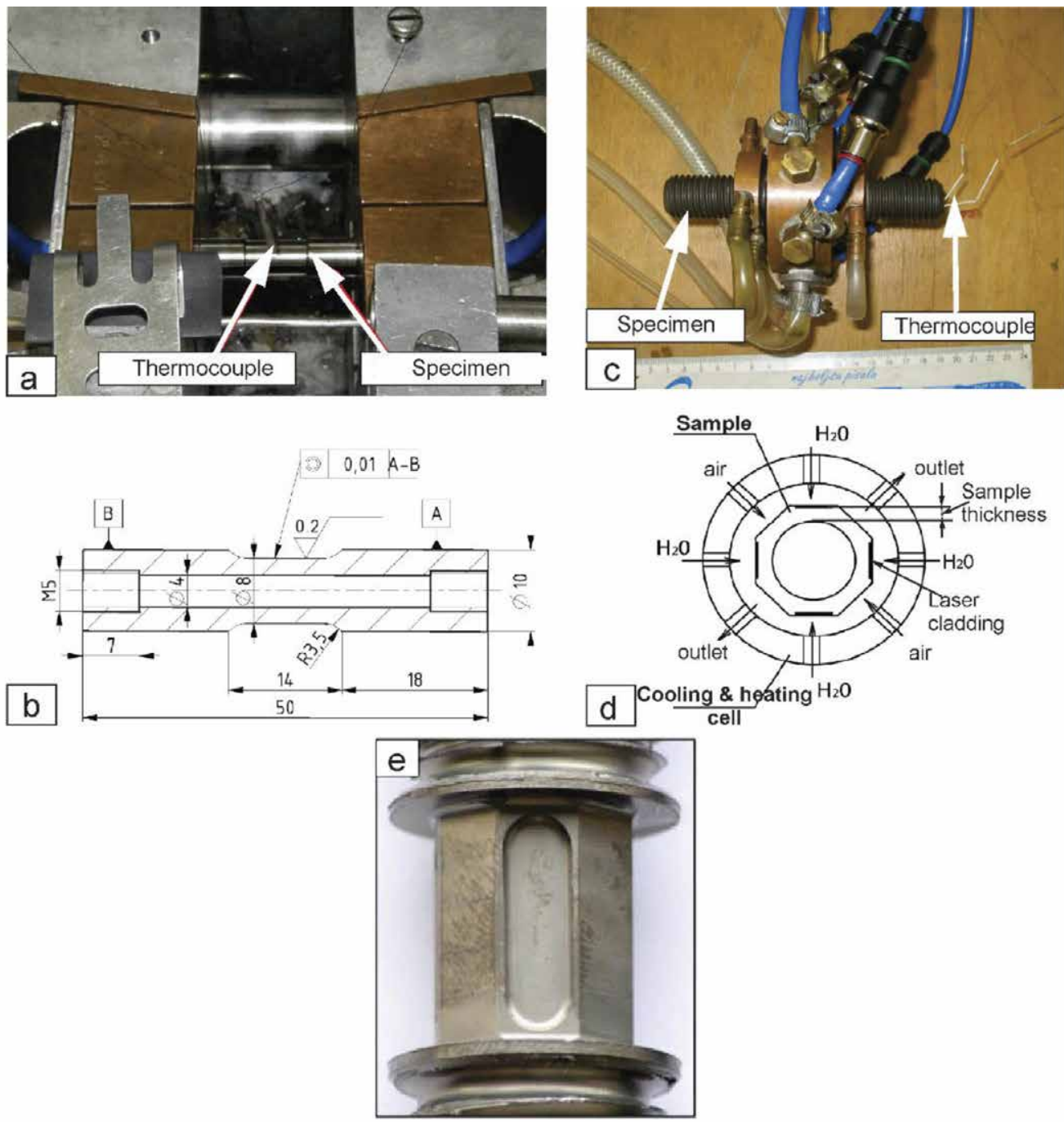

Figure 1: Test rigs for thermal fatigue testing; test rig 1 (a) with used specimen (b) and test rig 2 (c) with cross-section of octagonal specimens (d) and outer octagonal flat surface with machined slot for laser cladding (e).

ture in 3s which is followed by water cooling of specimen and emptying of specimen by air flow. Specific temperature gradient and consequently stress gradient is achieved on internal surface of specimen where occurrence of cracks is expected. Specimen was made from roll cast iron with following chemical composition: $3.10 \%$ C, $0.84 \% \mathrm{Si}, 0.86 \% \mathrm{Mn}, 1.71 \% \mathrm{Cr}, 0.3 \%$ Mo and 4.5\% Ni. Temperatures of 500, 600 and $700{ }^{\circ} \mathrm{C}$, respectively, were used for fatigue tests with evaluation and characterisation of cracks at 200, 500 and 1000 thermal cycles. For this purpose, samples were cut in radial as well as in axial direction. Characterization of cracks was focused inside length of $12 \mathrm{~mm}$ of central working length of samples. Time progress of temperature for several thermal cycles at test tem-

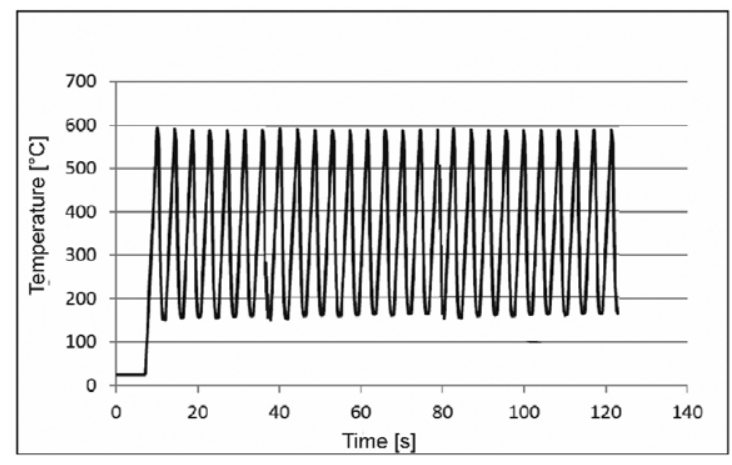

Figure 2: Thermal cycles at test rig 1.

perature of $600{ }^{\circ} \mathrm{C}$, i.e. including heating, water cooling and air cooling (emptying of specimen) of the specimens, is presented on Figure 2. 

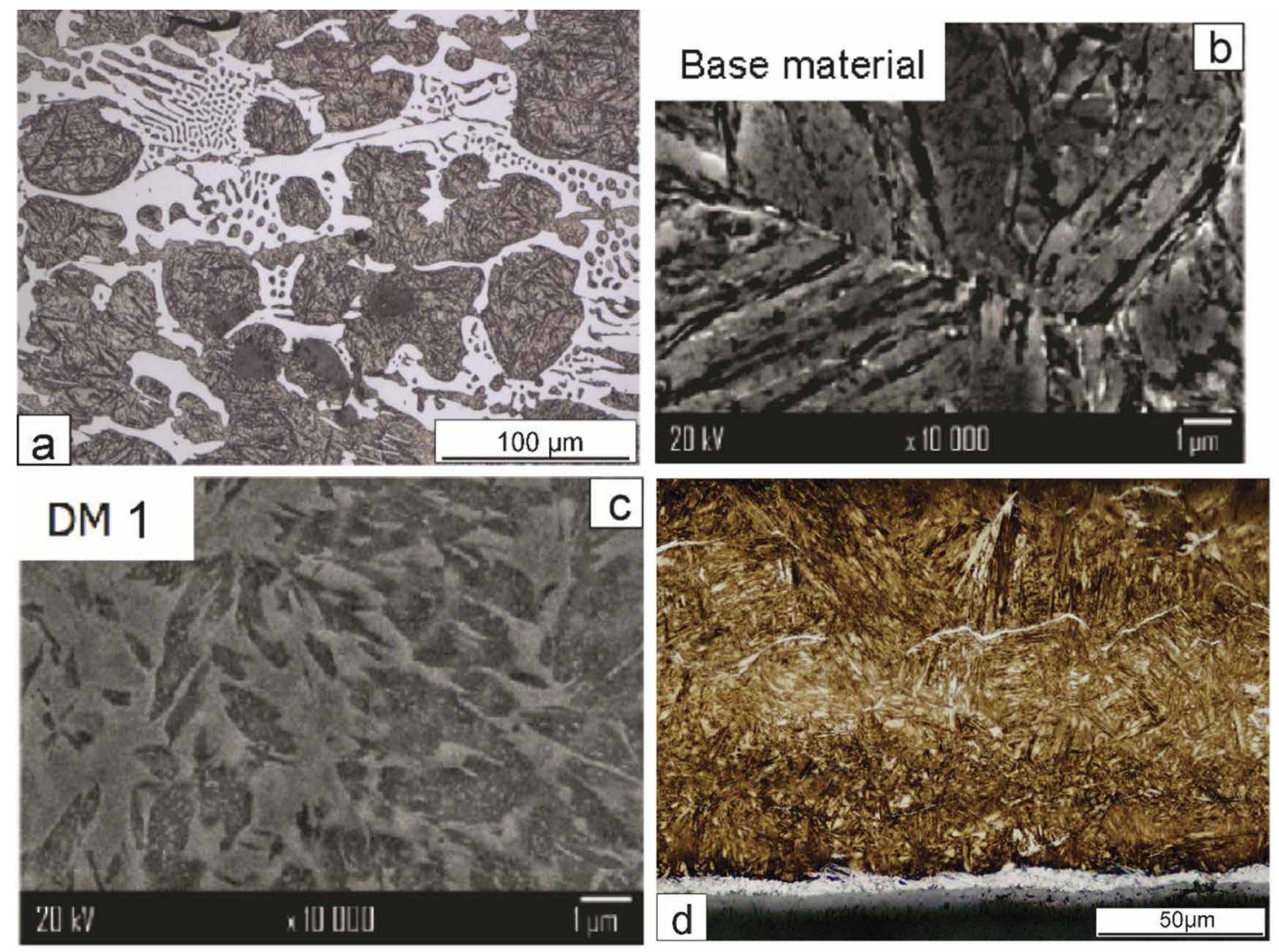

Figure 3: Initial microstructures; of roll cast iron - test rig 1 (a), of base material (b) and of laser cladding (DM 1) - test rig 2 (c), and on cross-section of nitrided surface layer - test rig 2 (d).

\section{Test rig 2, materials and test conditions}

The second test rig uses hollow (bore) specimen with circular or octagonal outer (external) shape with thermocouple of type K welded on internal side (bore), i.e. in the middle of working length of the octagonal specimen (Figures 1c-e) with mounted cooling system. Sample from tool steel with chemical composition: $0.35 \% \mathrm{C}, 1.12 \% \mathrm{Si}, 0.86 \% \mathrm{Mn}, 5.51 \% \mathrm{Cr}$, $0.30 \%$ Mo and $0.131 \% \mathrm{~V}$ is used. On the outside part of octagonal plane surface machined slots with depth of $0.5 \mathrm{~mm}$ were filled by laser cladding. Three filler materials with chemical composition similar to base material but different content for $\mathrm{Si}$ and $\mathrm{V}$ were used. In this case only one filler material will be presented and compared with base tool material. Used filler material (DM 1) contained $0.25 \% \mathrm{Si}$ and $0.13 \% \mathrm{~V}$. Different contents for $\mathrm{Si}$ and $\mathrm{V}$ in filler materials regarding to base material would also lead to different characteristics (size, amount, etc) of carbides and consequently also different thermal fatigue resistance can be expected [9]. Four surfaces of specimen are cooled from outside and consequently cracks are present on outside octagonal flat surface of specimen. The cooling and emptying process was optimized by a pair of magnetic computer controlled valves. One valve controlled the water quench and the other controlled the air compression to empty the cooling chamber. The valves were guided using the Gleeble 1500D control computer that was programmed simultaneously with the program for thermal fatigue of the specimen. At test rig 2 and laser cladding temperature of $650{ }^{\circ} \mathrm{C}$ was used for testing. Characteristics of cracks were evaluated at 2500, 5000 and 7500 thermal cycles. Thickness of sample wall in this case amounted $2.75 \mathrm{~mm}$ (see Figure 1d).

On other hand in case testing of nitrided sample its wall thickness amounted $3.25 \mathrm{~mm}$ whereas testing at 1000 cycles was interrupted.

\section{Characterization of microstructure}

Optical microscopy (OM, Carl Zeiss AXIO Imager.A1m) and an electron microscope JEOL 5610 


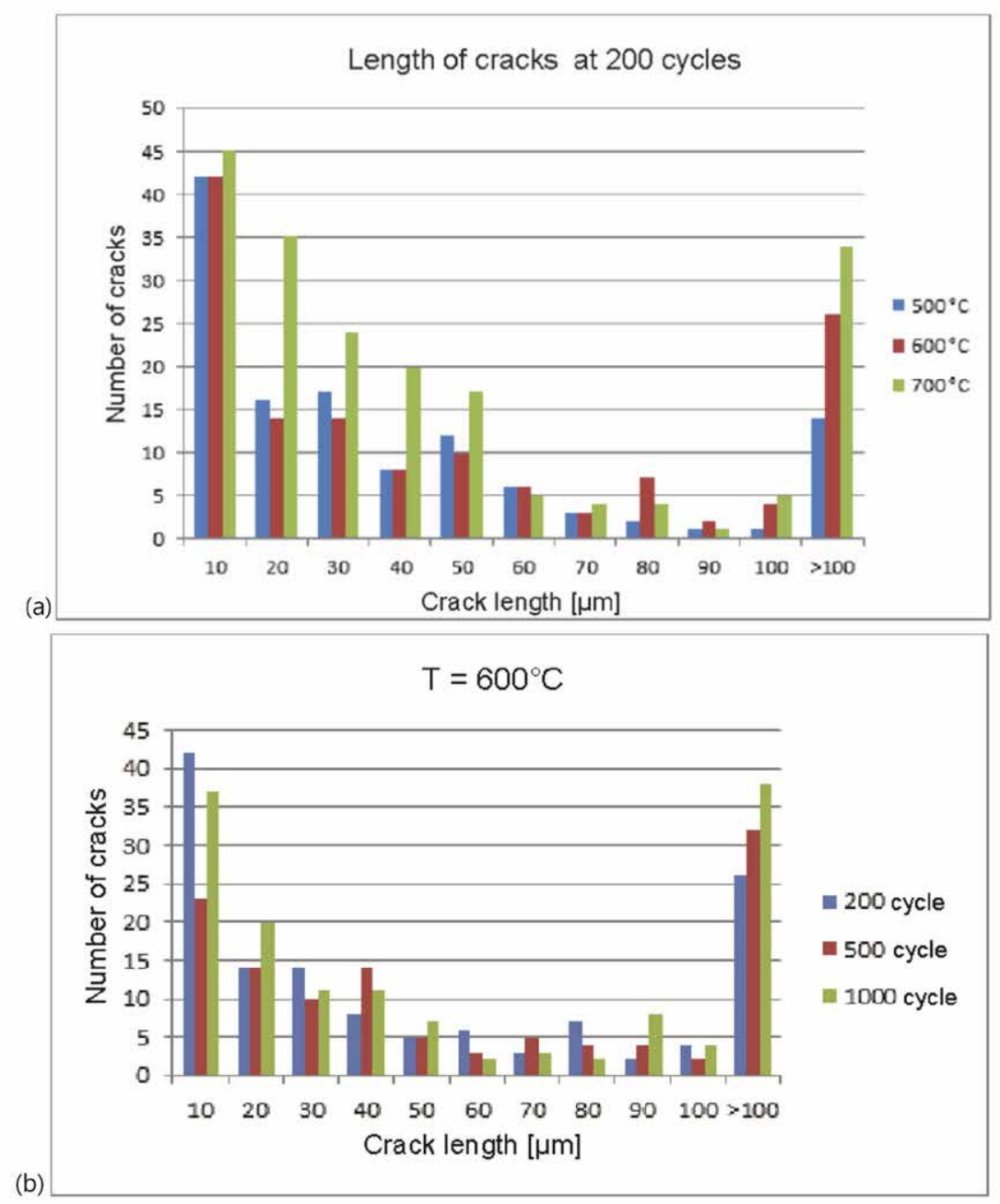

Figure 4: Number of cracks in relation to class length; at temperatures $500-700{ }^{\circ} \mathrm{C}$ and $200 \mathrm{cycles}(\mathrm{a})$, and at different number of cycles and test temperature of $600^{\circ} \mathrm{C}(b)$. Roll cast iron, test rig 1 .

were applied for observation of microstructure and characterization of cracks.

\section{Results}

\section{Microstructure of used materials}

On Figure 3a is presented microstructure of roll cast iron where martensitic matrix with cementite (carbides) and graphite is visible. On Figure $3 \mathrm{~b}$ microstructures of hot working tool steel (base material) while on Figure $3 \mathrm{c}$ microstructure for welding's (i.e. DM 1) are presented. The inspection of these microstructures revealed a considerable difference in the carbide content, while there are almost no secondary carbides visible in the specimen welded with the filler material 1 (Figure 3c). On the contrary carbides can be observed in base material (Figure 3b). The carbides in base material are of secondary and primary type, i.e. the ones that precipitated on grain boundaries of previous austenitic grains. Carbides mainly precipitated on grain boundaries that can represent weak areas (spots) regarding to thermal fatigue resistance. Additionally, also sample with nitrided surface (Figure 3d) was tested on thermal fatigue resistance. From the microstructure it is visible that thickness of compound layer in range of 7-10 $\mu \mathrm{m}$. Diffusion depth was about $150 \mu \mathrm{m}$ while maximal value for microhardness amounted ca $1100 \mathrm{Hv}$.

\section{Results for test rig 1}

Results of measurement of cracks length at 200 cycles and temperatures 500, 600 and 

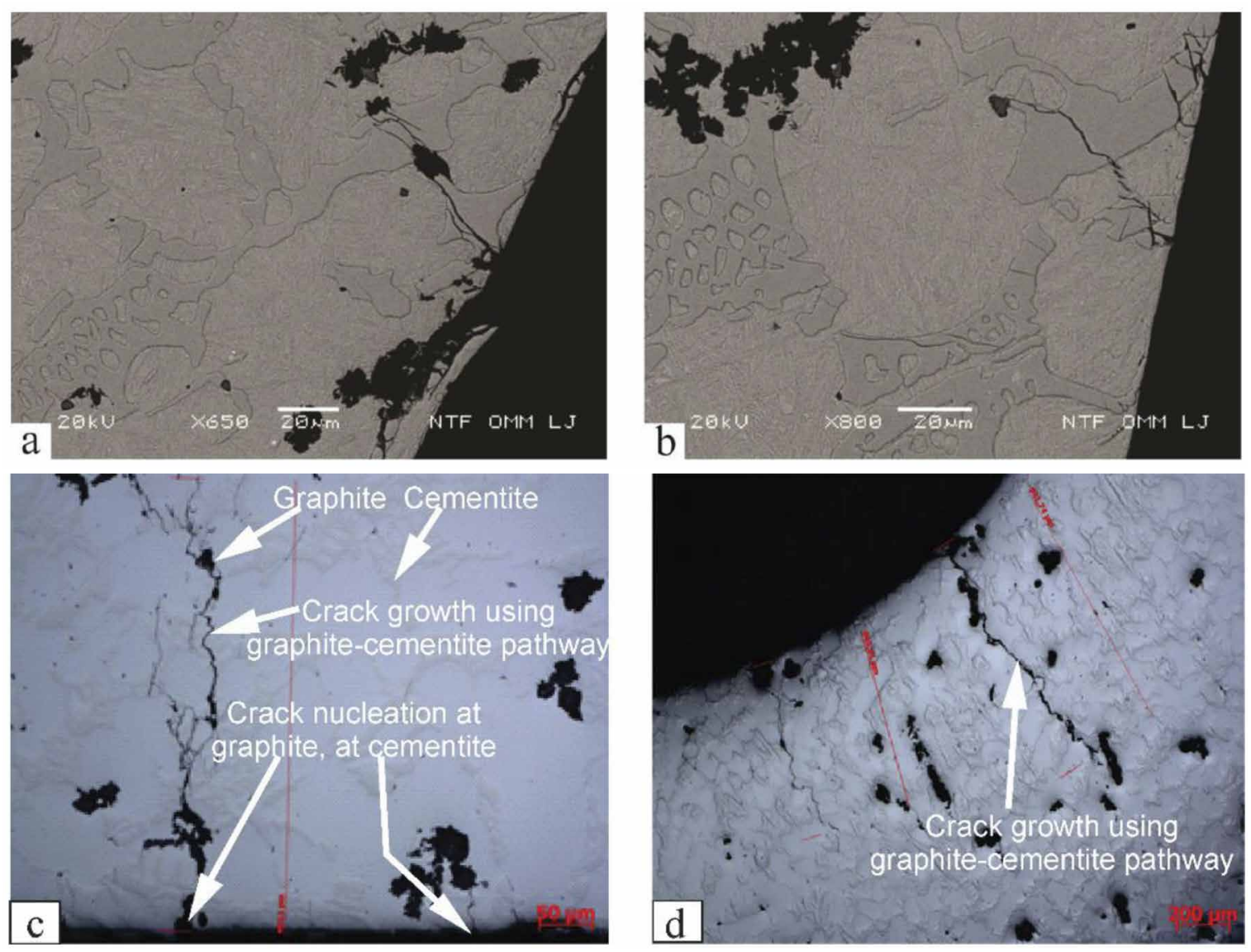

Figure 5: Crack nucleation at cementite and graphite (a), crack nucleation at cementite (b), crack nucleation at graphite and growth using graphite - cementite pathway $(c-d)$. Roll cast iron, test rig 1 .

$700{ }^{\circ} \mathrm{C}$ regarding the number of cracks revealed that number of cracks on working length of samples increases with increasing test temperature (see Figure 4a). Similar trends were obtained also in relation to other numbers of thermal cycles, i.e. 200,500 and 1000 . For test temperature of $600{ }^{\circ} \mathrm{C}$ results are presented in Figure $4 \mathrm{~b}$ where it can be seen that cracks initiate at cementite or graphite spots on cooled surface or close to cooled surface (Figure 5a-c). Propagation of cracks is mainly related to characteristics of cementite and graphite (Figure $5 c-d$ ), i.e. growth of cracks uses cementite and graphite pathways. With change of characteristics of cementite and graphite (i.e. size, amount, shape, distribution, etc.) which can be achieved by previous thermo-mechanical processing, chemical composition of roll cast iron, etc. can influence on time of initiation as well as on growth rate of cracks.

\section{Results for test rig 2}

Characteristics related to carbides of base material as well as of laser cladded materials in machined slots (DM 1) influence on cracking at testing of thermal fatigue resistance. At 7500 thermal cycles commencements of cracking on surface of DM 1 (Figure 6b) can be observed while appearance of increased cracking is visible at base material (Figure 6a). This difference can be attributed to lower content of Si in DM 1 in comparison to base material that influence the size and amount of carbides and consequently also the thermal fatigue resistance [9]. Furthermore, on outer flat surface of octagonal specimen various duplex treatments (nitriding plus CrN coating) with different nitriding and coating parameters can also be applied. At least four outside surfaces on specimen with various characteristics of prepared layers can be tested simultaneously. On Figure 7 appearance of nitrided surface at 1000 thermal cycling is presented. By comparing Figure 6a and Figure 7 it 

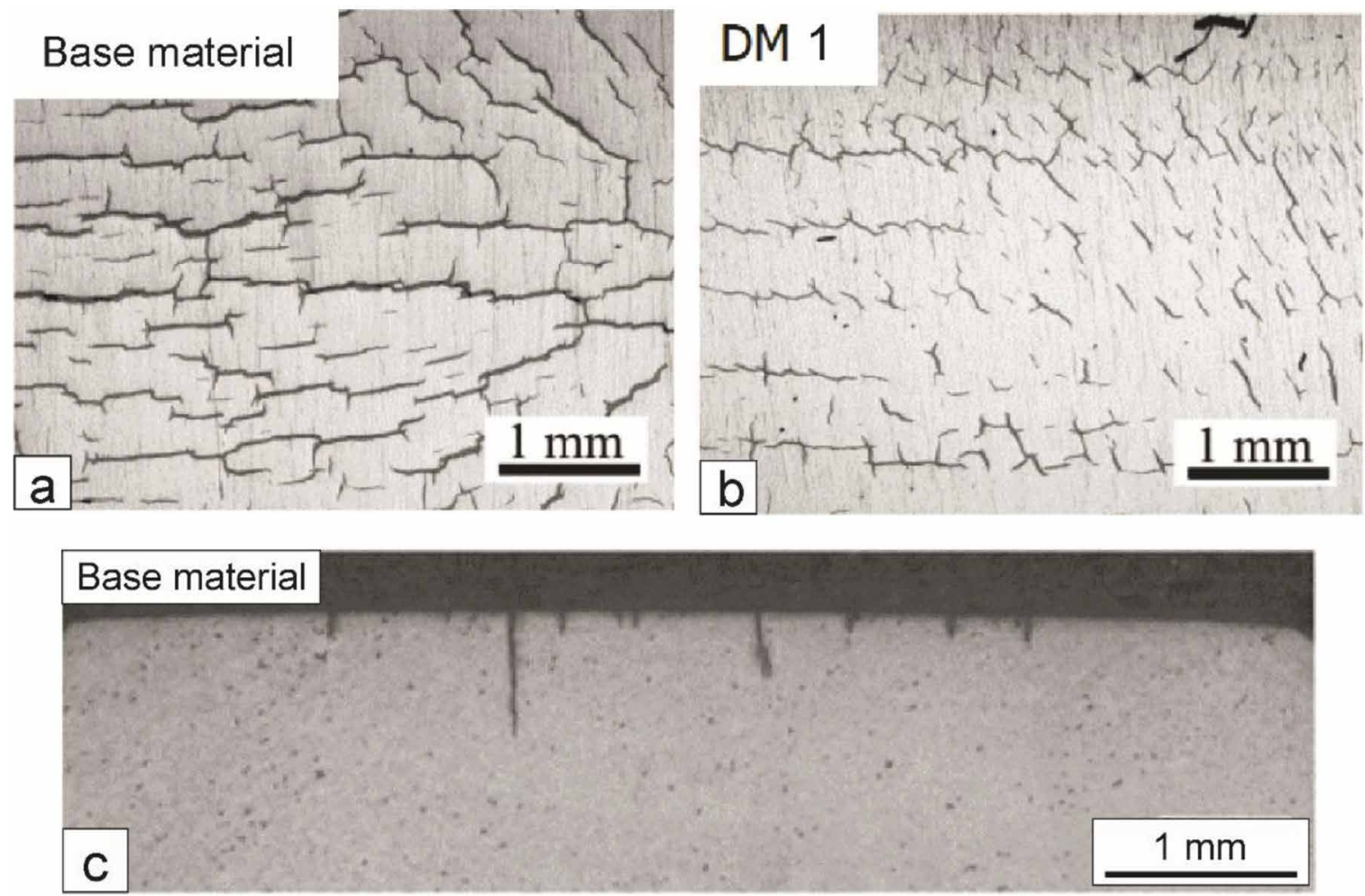

Figure 6: Comparison of appearance of surface cracking; of heat treated (base tool material) (a) and laser cladded surfaces (DM 1) (b) at 7500 thermal cycles, length of cracks on cross-section of tested base material (c), specimen thickness $2.75 \mathrm{~mm}$.

can be seen that density of cracks is increased for nitrided material that implies on their lower depth, i.e. in range $80-120 \mu \mathrm{m}$, in comparison to base material (Figure 6c) where lengths of cracks are around $600 \mu \mathrm{m}$. Note that specimen thickness of $3.25 \mathrm{~mm}$ (see Figure 1d) was used in this case. This increases stresses on tested surface layer during specimen cooling that in relation with increased brittleness of nitrided layer consequently also leads to increased density of cracks whereas their lengths are lower (Figure 7).

\section{Conclusions}

The following conclusions can be drawn from presented results:

- Two new thermal fatigue test rigs with computer guided heating and cooling of test specimens have been developed which enable testing at constant selected conditions.

- Test rig 1 characterized by internal cooling, is appropriate for study of thermal fa-

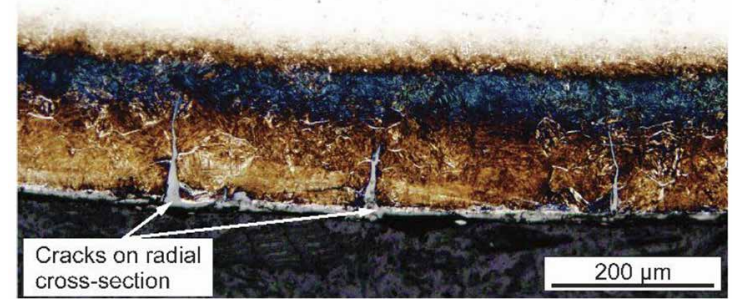

Figure 7: Appearance of duplex treated surface of nitrided sample at 1000 thermal cycles. Test rig 2, specimen thickness $3.25 \mathrm{~mm}$.

tigue resistance of base material, e.g. roll cast irons, roll steels, tool steels. It enables study of cracks nucleation, their growth and measurement of cracks length.

- In order to achieve higher thermal fatigue resistance of base material the tests rig 1 can serve as assessment of optimal parameters in process chain of roll cast iron (roll steel) production, i.e. solidifica- 
tion conditions, soaking temperature, hot working, heat treatment, etc.

- Test rig 2, i.e. with external cooling, is appropriate for study of thermal fatigue resistance of tool surfaces that are laser cladded, duplex treated, etc.

- Ability of comparative testing of several differently prepared surface layers simultaneously by test rig 2 increases accuracy of obtained results on their thermal fatigue resistance.

- Both tests enable achieving different temperature gradients at same (maximal) test temperature.

\section{References}

[1] Garza Montes de Oca, N.F., Colas, R., Rainfort, W.M. (2011): On the damage of work roll grade high speed steel by thermal cycling. Engineering Failure analysis, 18, pp. 1576-1583.

[2] Haddler, N., Fissolo, A., Maillot, V. (2005): Thermal fatigue crack networks: a computational study. International Journal of Solids and Structures, 42, pp. 771-788.

[3] Persson, A., Hogmark, S., Bergström, J. (2004): Simulation and evaluation of thermal fatigue cracking of hot work tool steel. International Journal of Fatigue, 26, pp. 1095-1107.

[4] Amiable, S., Chapuliot, S., Constantinescu, A., Fissolo, A. (2006): A comparison of life time prediction methods for a thermal fatigue experiment. International Journal of Fatigue, 28, pp. 692-706.

[5] Absi, J., Glandus, J.C. (2004): Improved methods for severe thermal shocks testing of ceramics by water quenching. Journal of European Ceramic society, 24, pp. 2835-2838.

[6] Marsh, D.J. (1981): A thermal shock fatigue study of type 304 and 316 stainless steels. Fatigue of Engineering Materials and Structures, 4/2, pp. 179-195.

[7] Hadder, N., Fissolo, A. (2005): 2D simulation of the initiation and propagation of crack array under thermal fatigue. Nuclear Engineering and Design, 235, pp. 945-964.

[8] Pellizzari, M., Molinari, A., Straffelini, G. (2003): Thermal fatigue resistance of gas and plasma nitrided 41CrAlMo7 steel. Materials Science and Engineering, 352, pp. 186-194.

[9] Delagnes, D., Lamesle, P., Mathon, M.H., Mebarki, N., Levaillant, C. (2005): Influence of silicon content on the precipitation of secondary carbides and fatigue properties of a $5 \% \mathrm{Cr}$ tempered martensitic steel. $M a$ terials Science and Engineering, 394, pp. 435-444. 